This is the author's final, peer-reviewed manuscript as accepted for publication. The publisher-formatted version may be available through the publisher's web site or your institution's library.

\title{
Inhibition of norovirus 3CL protease by bisulfite adducts of transition state inhibitors
}

Sivakoteswara Rao Mandadapu, Mallikarjuna Reddy Gunnam, Kok-Chuan Tiew, Roxanne Adeline Z. Uy, Allan M. Prior, Kevin R. Alliston, Duy H. Hua, Yunjeong Kim, Kyeong-Ok Chang, William C. Groutas

\section{How to cite this manuscript}

If you make reference to this version of the manuscript, use the following information:

Mandadapu, S. R., Gunnam, M. R., Tiew, K., Uy, R. A. Z., Prior, A. M., Alliston, K. R., . . . Groutas, W. C. (2013). Inhibition of norovirus 3CL protease by bisulfite adducts of transition state inhibitors. Retrieved from http://krex.ksu.edu

\section{Published Version Information}

Citation: Mandadapu, S. R., Gunnam, M. R., Tiew, K., Uy, R. A. Z., Prior, A. M., Alliston, K. R., . . . Groutas, W. C. (2013). Inhibition of norovirus 3CL protease by bisulfite adducts of transition state inhibitors. Bioorganic \& Medicinal Chemistry Letters, 23(1), 62-65.

Copyright: (c) 2012 Elsevier Ltd.

Digital Object Identifier (DOI): doi:10.1016/j.bmcl.2012.11.026

Publisher's Link:

http://www.sciencedirect.com/science/article/pii/S0960894X12014692

This item was retrieved from the K-State Research Exchange (K-REx), the institutional repository of Kansas State University. K-REx is available at http://krex.ksu.edu 


\section{Inhibition of Norovirus 3CL Protease by Bisulfite Adducts of Transition State Inhibitors}

Sivakoteswara Rao Mandadapu, ${ }^{\text {a,\# }}$ Mallikarjuna Reddy Gunnam, ${ }^{a, \#}$ Kok-Chuan Tiew, ${ }^{a}$, Roxanne Adeline Z. Uy, ${ }^{a}$ Allan M. Prior, ${ }^{b}$ Kevin R. Alliston, ${ }^{a}$ Duy H. Hua, ${ }^{b}$ Yunjeong Kim, ${ }^{c}$ Kyeong-Ok Chang, ${ }^{c}$ William C. Groutas ${ }^{a *}$

${ }^{a}$ Department of Chemistry, Wichita State University, Wichita, Kansas 67260, USA

${ }^{b}$ Department of Chemistry, Kansas State University, Manhattan, Kansas 66506, USA

'Department of Diagnostic Medicine/Pathobiology, College of Veterinary Medicine, Kansas State University, Manhattan, Kansas 66506, USA

\#these authors contributed equally to this work *author to whom correspondence should be addressed.

Department of Chemistry, Wichita State University, Wichita, KS 67260

Tel. (316) 978 7374; Fax: (316) 9783431

e-mail: bill.groutas@wichita.edu 


\section{Abstract}

Noroviruses are the most common cause of acute viral gastroenteritis, accounting for $>21$ million cases annually in the U.S. alone. Norovirus infections constitute an important health problem for which there are no specific antiviral therapeutics or vaccines. In this study, a series of bisulfite adducts derived from representative transition state inhibitors (dipeptidyl aldehydes and $\alpha$-ketoamides) was synthesized and shown to exhibit anti-norovirus activity in a cell-based replicon system. The $\mathrm{ED}_{50}$ of the most effective inhibitor was $60 \mathrm{nM}$. This study demonstrates for the first time the utilization of bisulfite adducts of transition state inhibitors in the inhibition of norovirus $3 \mathrm{CL}$ protease in vitro and in a cell-based replicon system. The approach described herein can be extended to the synthesis of the bisulfite adducts of other classes of transition state inhibitors of serine and cysteine proteases, such as a-ketoheterocycles, a-ketoesters, and others. 
Noroviruses are a major cause of waterborne and foodborne acute gastroenteritis. ${ }^{1-4}$ Outbreaks of viral gastroenteritis are common because of the highly contagious nature of noroviruses. Noroviral gastroenteritis is the cause of significant morbidity and may lead to fatal infection in children, the elderly, and immuno-compromised individuals. ${ }^{5}$ There are currently no effective vaccines or antiviral agents for combating norovirus infection; consequently, there is an urgent need for the discovery of small molecule therapeutics for the management and treatment of norovirus infection. ${ }^{6-7}$ Recentlyreported small molecule norovirus inhibitors include cyclic and acyclic sulfamide derivatives, ${ }^{8-10}$ piperazine derivatives, ${ }^{11}$ pyranobenzopyrones, ${ }^{12}$ nitazoxanide $^{13}$ and other chemotypes. ${ }^{14}$

The norovirus RNA genome encodes a polyprotein which is processed by a virusencoded 3C-like cysteine protease (3CLpro) to generate mature non-structural proteins. ${ }^{15}$ Co- and post-translational processing of the polyprotein by norovirus 3CLpro is essential for virus replication; consequently, norovirus 3 CLpro is an attractive target for the discovery of anti-norovirus small molecule therapeutics.

We have recently demonstrated that peptidyl aldehydes, ${ }^{16} \alpha$-ketoamides,${ }^{17}$ and $\alpha$ ketoheterocycles ${ }^{17}$ potently inhibit norovirus 3 CLpro in vitro, as well as norovirus in a cell-based replicon system. In an attempt to identify suitably-functionalized dipeptidyl transition state inhibitors that possess potent pharmacological activity, as well as molecular properties that are important for oral bioavailability and favorable ADMET characteristics, ${ }^{18-24}$ we describe herein for the first time the synthesis of bisulfite adducts of transition state inhibitors and their subsequent utilization in the inhibition of norovirus 3CLpro in vitro, as well as viral replication in a cell-based replicon system (Figure 1). To 
the best of our knowledge, this is the first report on the use of bisulfite adducts of transition state inhibitors to inhibit a protease. We furthermore describe the results of preliminary structure-activity relationship studies related to the probing of the $S_{2}$ subsite $^{25}$ of norovirus 3 CLpro, as well as the nature of the "cap" that projects toward the $\mathrm{S}_{3}$ subsite and beyond.

[Figure 1]

The synthesis of dipeptidyl inhibitors $\mathbf{6 a - j , 7 a - j , ~ 9 , ~ a n d ~} \mathbf{1 0}$ is summarized in Scheme 1.

[Scheme 1]

Reaction of an appropriate amino acid ester hydrochloride with trichloromethyl chloroformate yielded the corresponding isocyanate which was subsequently reacted with an appropriate alcohol in the presence of triethylamine to yield carbamate derivative 2. Hydrolysis with lithium hydroxide in aqueous THF followed by coupling with a glutamine surrogate ${ }^{26}$ yielded ester 4 which was further elaborated to yield aldehydes 6a-j via sequential reduction to the alcohol with lithium borohydride, followed by DessMartin oxidation. ${ }^{27}$ The reaction of aldehyde $6\left(R^{1}=\right.$ benzyl, $R^{2}=$ isobutyl) with cyclopropyl isonitrile/HOAc followed by treatment with potassium carbonate in aqueous methanol yielded alcohol 8 which was then oxidized to the corresponding a-ketoamide 9 using Dess-Martin reagent. The generated aldehyde and a-ketoamide bisulfite adducts were readily obtained by stirring aldehydes $6 a-j$ and $\alpha$-ketoamide 9 with sodium bisulfite. $^{28}$ The interaction of the generated compounds with norovirus 3CLpro was investigated in vitro as previously described. ${ }^{16-17}$ The activity of the compounds against 
norovirus was also investigated in a cell-based system ${ }^{29-33}$ and the combined results are listed in Table 1.

\section{[Table 1]}

The rationale underlying the studies described herein rested on the following considerations: (a) bisulfite adducts of amino acid-derived isocyanates are readilyaccessible, stable, water-soluble solids which function as latent isocyanates. These adducts have been shown to be highly effective, time-dependent, irreversible inhibitors of mammalian serine proteases, such as neutrophil elastase, cathepsin G, and proteinase $3 ;^{34}$ (b) bisulfite adducts of aldehydes, methyl or cyclic ketones, and $\alpha$ ketoesters are readily-synthesized, stable solids having high aqueous solubility. Treatment of the addition products with acid or base yields the precursor carbonyl compounds; ${ }^{35}$ (c) we hypothesized that the bisulfite adducts of transition state (TS) inhibitors of proteases (serine and cysteine), such as peptidyl aldehydes, $\alpha$-ketoamides, and others could potentially function as a latent form of the precursor TS inhibitor (Figure 1), generating the active form of the inhibitor in the gastrointestinal tract and blood plasma. In principle, the bisulfite adducts could also function as transition state mimics $^{36}$ and, (d) the high aqueous solubility and $\mathrm{pH}$-dependent equilibria between the precursor carbonyl compound and adduct were also envisaged to have a significant effect on potency and the ADMET and PK characteristics of the precursor TS inhibitors. It was envisioned that the bisulfite adducts might be suitable candidates for fulfilling such a role. 
As shown in Table 1 the dipeptidyl aldehydes exhibited low to sub-micromolar inhibitory activity toward NV 3CLpro in vitro. The enzyme shows a strong preference for an $R^{2}=$ isobutyl, which is in agreement with the known substrate specificity of the enzyme. The strong preference of NV 3CLpro for a P2 Leu is supported by substrate specificity studies using peptidyl $p$-nitroanilide substrates, as well as X-ray crystallographic studies. ${ }^{37}$ The results in Table 1 suggest that replacement of the isobutyl group by a cyclohexylmethyl group at $R^{2}$ yields an inhibitor that is equipotent to $\mathbf{6 a}$ (Table 1, compounds $\mathbf{6 a}$ and $\mathbf{6 d}$ ). However, in sharp contrast to compound $\mathbf{6 a}$, the $\mathrm{ED}_{50}$ of compound $\mathbf{6 \boldsymbol { d }}$ was found to be an order of magnitude lower than that of $\mathbf{6 a}$, presumably because of its better cellular permeability. The nature of the "cap" $\left(R^{1}\right)$ which projects toward the $S_{3}$ pocket and beyond was briefly explored by replacing the benzyl group with meta- and para-fluorobenzyl, 2-phenylethyl, and 2-cyclohexylethyl. The $m$-fluorobenzyl and 2-cyclohexylethyl groups were equipotent to the benzyl group, and about 2-fold better than other substitutions (Table 1, compounds $\mathbf{6 a}, \mathbf{6 g}, \mathbf{6 j}$ versus $6 f$ and $6 j)$.

The activity of the bisulfite adducts of the synthesized aldehydes was investigated in a cell-based system. The potency trends observed with the precursor aldehydes were generally reflected in the corresponding bisulfite salts, with bisulfite $7 d\left(R^{2}=\right.$ cyclohexylmethyl) being the most potent. In order to determine the nature of the active species, the behavior of aldehyde $6 \mathbf{a}$ and its corresponding bisulfite salt $7 \mathbf{a}$ was examined by mass spectroscopy. In separate experiments, compounds $6 \mathbf{a}$ and $7 \mathbf{a}$ were dissolved in dimethyl sulfoxide and diluted 1 to 1000 in either acetonitrile or water and examined by MS and tandem MS-MS. In acetonitrile the expected peaks for aldehyde 
6a were $404.4 \mathrm{M}+\mathrm{H}^{+}$(dominant peak) and $426.3 \mathrm{M}+\mathrm{Na}$. The mass spectra of bisulfite salt 7a using negative mode detection, showed a dominant peak at 484.5 for $(\mathrm{M}-1)^{-}$, a loss of $\mathrm{H}^{+}$from the sulfonic acid moiety. Aldehyde $\mathbf{6} \mathbf{a}$ in aqueous solution showed peaks corresponding to the aldehyde (404.6), the aldehyde + sodium (426.4) and hydrated aldehyde + sodium (444.2) in positive mode. In water, bisulfite adduct $7 a$ displayed a dominant peak at 484.5 in negative mode and the relative intensities of this parent ion and other ions remained unchanged over 24 hours (a time course study was carried out). In the case of $\mathbf{6 a}$, the hydrated form was the dominant species after only five minutes exposure to water, while $7 a$ remains unchanged as the bisulfite form after 24 hours. The results indicate that the hydroxyl bisulfite functionality of $\mathbf{7 a}$ is stable in aqueous solution. In pH 7.4 buffer solution, however $7 a$ gradually dissociates to the corresponding aldehyde $\mathbf{6 a}$ (results obtained from mass spectrometry study), which is in agreement with the results of X-ray crystallographic studies showing that incubation of bisulfite adduct $7 a$ with norovirus 3CLpro in buffer solution results in the formation of an enzyme-aldehyde complex with the active site cysteine residue covalently bonded to the carbonyl carbon of aldehyde $6 \mathbf{a}^{33}$

In summary, the utilization of bisulfite adducts of transition state inhibitors of serine and cysteine proteases in the in vitro and cell-based inhibition of norovirus $3 \mathrm{CL}$ protease has been described for the first time. 


\section{References and Notes}

Key words: norovirus $3 C L$ protease; bisulfite salt adducts; transition state inhibitors

${ }^{*}$ Corresponding author. Tel. +1 316978 7374; Fax +1 316978 3431; e-mail: bill.groutas@wichita.edu

1. Karst, S. M. Viruses 2010, 2, 748.

2. Koo, H. L.; Ajami, N.; Atmar, R. L.; DuPont, H. L. Discov. Med. 2010, 10, 61.

3. Eckardt, A. J.; Baumgart, D. C. Rec. Patents Anti-infect. Drug Discov. 2011, 6, 54.

4. Atmar, R. L. Food Environ. Virol. 2010, 2, 117.

5. Khan, M. A.; Bass, D. M. Curr. Opin. Gastroenterol. 2010, 26, 26.

6. Tan, M.; Jiang, X. Curr. Opin. Investig. Drugs 2008, 9, 146.

7. Glass, R. I.; Parashar, U. D.; Estes, M. K. New Engl. J. Med. 2009, 361, 1776.

8. Dou, D.; Tiew, K-C.; He, G.; Mandadapu, S. R.; Aravapalli, S.; Alliston, K. R.; Kim, Y.; Chang, K-O.; Groutas, W. C. Bioorg. Med. Chem. Lett. 2011, 19, 5975.

9. Dou, D.; Mandadapu, S. R.; Alliston, K. R.; Kim, Y.; Chang, K-O.; Groutas, W. C. Eur. J. Med. Chem. 2012, 47: 59.

10. Dou, D.; Tiew, K-C.; He, G.; Mandadapu, S. R.; Gunnam, M. R.; Alliston, K. R.; Kim, Y.; Chang, K-O.; Groutas, W. C. Bioorg. Med. Chem. 2012, 20, 2111.

11. Dou, D.; He, G.; Mandadapu, S. R.; Aravapalli, S.; Kim, Y.; Chang, K-O.; Groutas, W. C. Bioorg. Med. Chem. Lett. 2012, 22, 377.

12. Pokheil, L.; Kim, Y.; Thi, D.; Nguyen, T.; Prior, A. M.; Lu, J.; Chang, K-O.; Hua, D. H. Bioorg. Med. Chem. Lett. 2012, 22, 3480. 
13. Siddiq, D. M.; Koo, H. L.; Adachi, J. A.; Viola, G. M. J. Infect. 2011, 63, 394.

14. Dou, D.; Mandadapu, S. R.; Alliston, K. R.; Kim, Y.; Chang, K-O.; Groutas, W. C. Bioorg. Med. Chem. 2011, 19, 5749.

15. Blakeney, S. J.; Cahill, A.; Reilly, P. A. Virology 2003, 308, 216.

16. Tiew, K-C.; He, G.; Aravapalli, S.; Mandadapu, S. R.; Gunnam, M. R.; Alliston, K. Lushington, G. H.; Kim, Y.; Chang, K-O.; Groutas, W. C. Bioorg. Med. Chem. Lett. 2011, 21, 5315.

17. Mandadapu, S. R.; Weerawarna, P. M.; Gunnam, M. R.; Alliston, K.;

Lushington, G. H.; Kim, Y.; Chang, K-O.; Groutas, W. C. Bioorg. Med. Chem. Lett. 2012, 22, 4820-4826.

18. Lipinski, C. A. J. Pharmacol. Toxicol. Meth. 2000, 44, 235.

19. Veber, D. F. J. Med. Chem. 2002, 45, 2615.

20. Ritchie, T. J.; Ertl, P.; Lewis, R. Drug Discov. Today 2011, 16, 65.

21. Gleeson, M. P. J. Med. Chem. 2008, 51, 817.

22. Johnson, T. W.; Dress, K. R.; Edwards, M. Bioorg. Med. Chem. Lett. 2009, 19, 5560.

23. Perola, E. J. Med. Chem. 2010, 53, 2986.

24. Edwards, M. P.; Price, D. A. Ann. Rep. Med. Chem. 2010, 45, 381.

25. Schechter, I.; Berger, A. Biochem. Biophys. Res. Comm. 1967, 27, 157. The residues on the $\mathrm{N}$-terminus side of the peptide bond that is cleaved are designated $P_{1}-P_{n}$ and those on the $C$-terminus side are designated $P_{1}{ }^{\prime}-P_{n}{ }^{\prime}$. The corresponding active site subsites are designated $S_{1}-S_{n}$ and $S_{1}{ }^{\prime}-S_{n}$. 
26. Dragovich, P. S.; Prins, T. J.; Zhou, R.; Webber, S. E.; Marakovits, J. T.; Fuhrman, S. A.; Patick, A. K.; Matthews, D. A.; Lee, C. A.; Ford, C. E.; Burke, B. J.; Rejto, P. A.; Hendrickson, T. F.; Tuntland, T.; Brown, E. L.; Meador, J. W.; Ferre, R. A.; Harr, J. E. V.; Kosa, M. B.; Wortland, S. T. J. Med. Chem. 1999, 42, 1213.

27. (a) Dess, D. B.; Martin, J. C. J. Org. Chem. 1983, 48, 4155; (b) Wells, G. J.; Tao, M. T.; Josef, K. A.; Bihovsky, R. J. Med. Chem. 2001, 44, 3488-3503.

28. General synthesis of bisulfite salts. The procedure used was essentially that of Kjell, D. P.; Slattery, B. J.; Semo, M. J. J. Org. Chem. 1999, 64, 5722-5724. Briefly, aldehyde or a-ketoamide $(1.24 \mathrm{mmol})$ was dissolved in ethyl acetate $(2 \mathrm{~mL})$ and a solution of sodium bisulfite $(1.12 \mathrm{mmol})$ in ethanol $(1 \mathrm{~mL})$ and water $(0.4 \mathrm{~mL})$ was added. The mixture was heated to $40^{\circ} \mathrm{C}$ with stirring. After the mixture was stirred for $2 \mathrm{~h}$, it was allowed to cool to room temperature. The solution was filtered and the solid residue was washed with ethanol $(5 \mathrm{~mL})$. The filtrate was dried over anhydrous sodium sulfate, filtered, and concentrated, leaving an oily residue. Treatment with ether gave a solid $(60-80 \%$ yield).

29. Chang, K. O.; Sosnovtsev, S. V.; Belliot, G.; King, A.D.; Green, K. Y. Virology 2006, 2, 463.

30. Chang, K. O.; George, D. W. J. Virol. 2007, 22, 12111.

31. Chang, K. O. J. Virol. 2009, 83, 8587.

32. Kim, Y.; Thapa, M.; Hua, D. H.; Chang, K-O. Antiviral Res. 2011, 89, 165.

33. Kim, Y.; Lovell, S.; Tiew, K. C.; Mandadapu S. R.; Alliston, K. R.; Battaille, K. P.; Groutas, W. C.; Chang, K. O. J. Virol. 2012 Aug 22 [Epub ahead of print]. PIMD:22915796. 
34. (a) Groutas, W. C.; Abrams, W. R.; Theodorakis, M. C.; Kasper, A. M.; Rude, S. A.; Badger, R. C.; Ocain, T. D.; Miller, K. E.; Moi, M. K.; Brubaker, M. J.; Davis, K. S.; Zandler, M. E. J. Med. Chem. 1985, 28, 204. (b) Groutas, W. C.; Brubaker, M. J.; Stanga, M. A.; Castrisos, J. C.; Huang, T. L.; Crowley, J. P. Biochem. Biophys. Res. Comm. 1985, 128, 90.

35. Young, P. R.; Jencks, W. P. J. Am. Chem. Soc. 1978, 100, 1228.

36. Patel, D. V.; Rielly-Gauvin, K.; Ryono, D. E. Tetrahedron Lett. 1990, 31, 5587.

37. Hussey, R. J.; Coates, L.; Gill, R. S.; Erskine, P. T.; Coker, S-F.; Mitchell, E.; Cooper, B.; Wood, S.; Broadbridge, R.; Clarke, I. N.; Lambden, P. R.; Scholingin-Jordan, M. P. Biochemistry 2011, 50, 240. 
Table 1. Inhibitory activity of compounds $6,7 a-j, 9,10$<smiles>[R]OC(=O)NC([R2])C(=O)N[C@@H]([R])C[C@@H]1CCNC1=O</smiles>

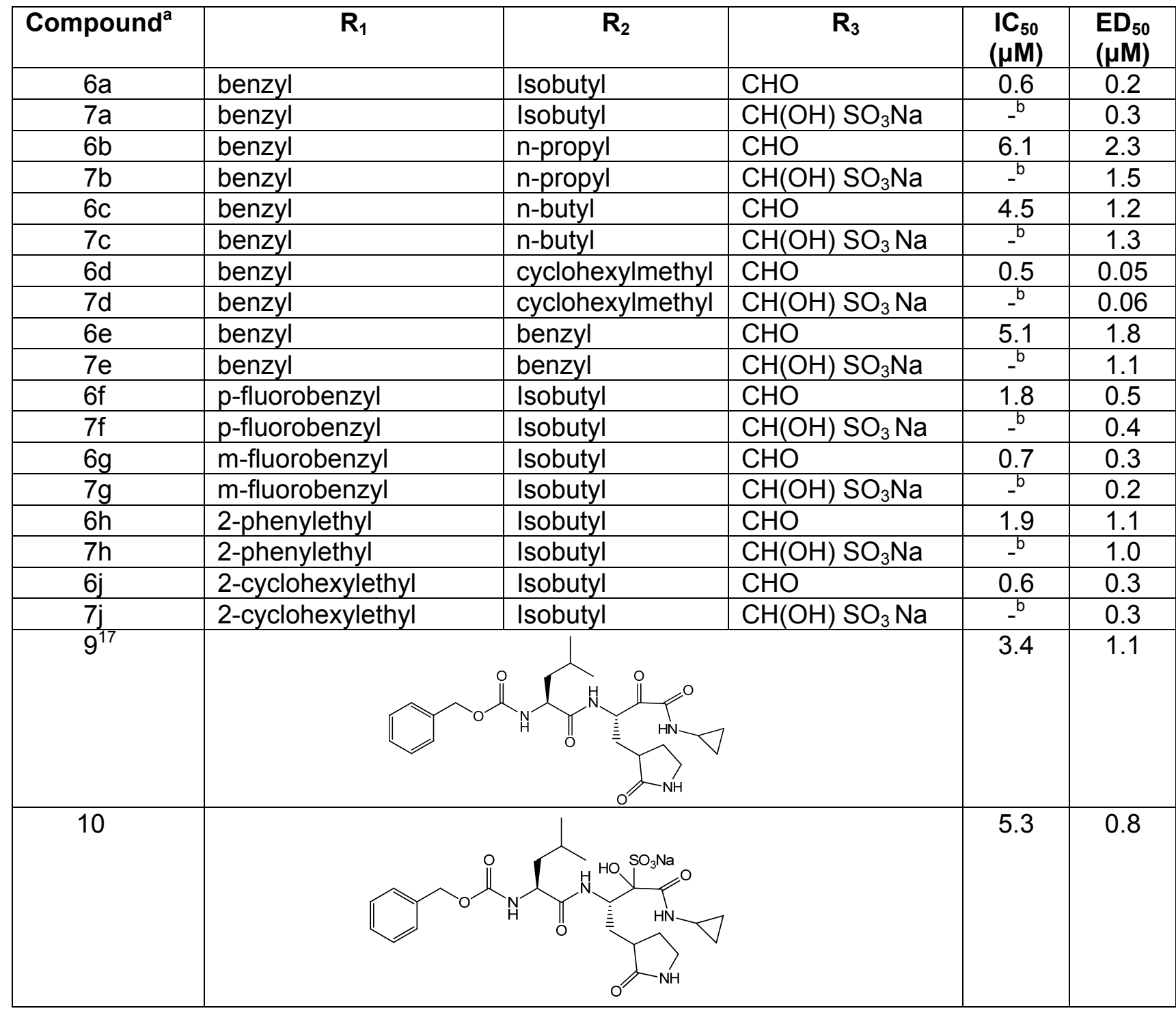

${ }^{\mathrm{a}} \mathrm{CC}_{50}$ : All compounds, except $\mathbf{6 j}$ and $\mathbf{7 j}$, showed no toxicity up to $320 \mu \mathrm{M}\left(\mathrm{CC}_{50}\right.$ : > $320 \mu \mathrm{M})$. The $\mathrm{CC}_{50}$ values for $6 j$ and $7 j$ were $210 \mu \mathrm{M}$, and $240 \mu \mathrm{M}$, respectively.

${ }^{b}$ Not determined (see text). 


\section{Scheme 1}<smiles>[R]OC(=O)NC([R2])C(=O)NC([R2])C(=O)OC</smiles>

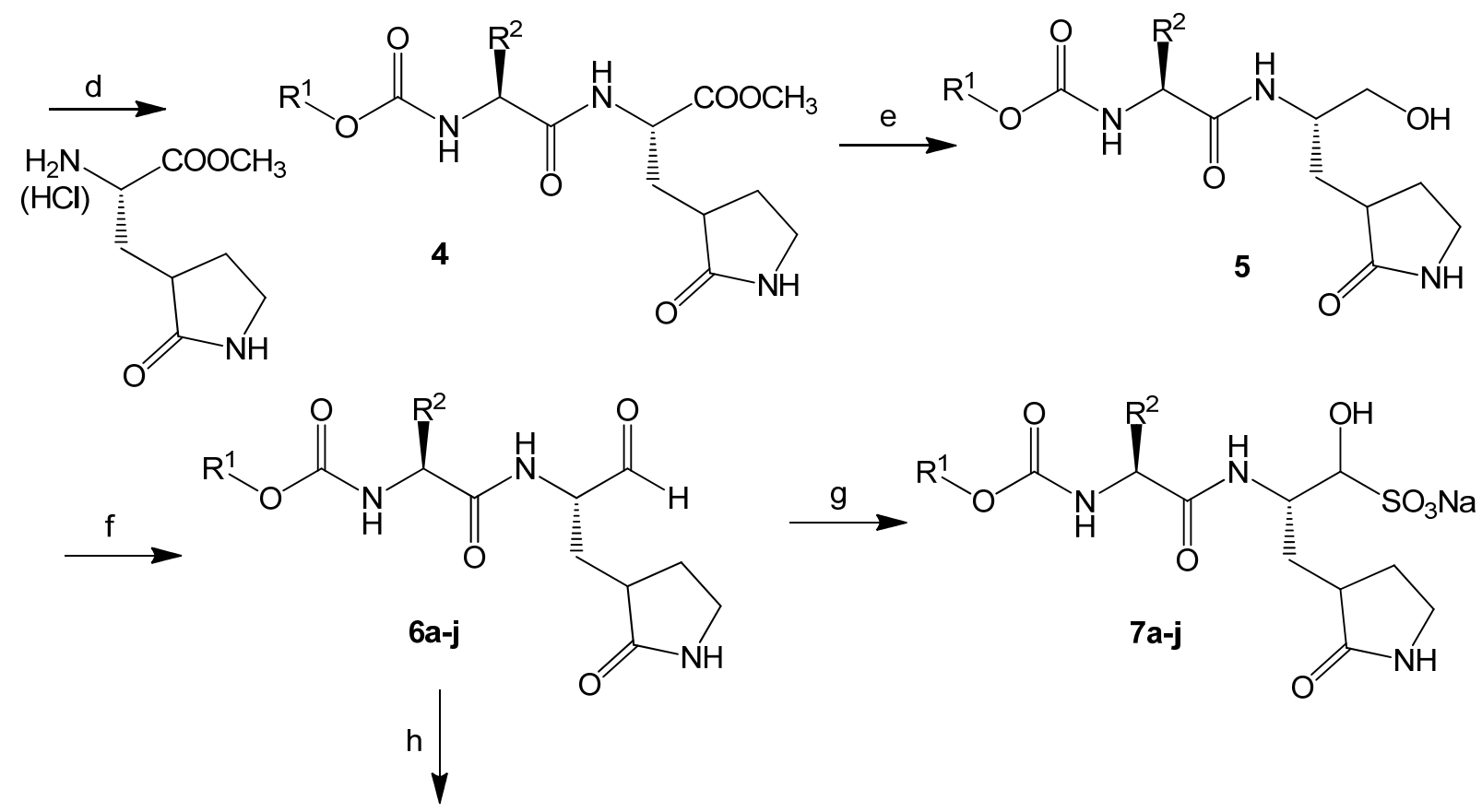

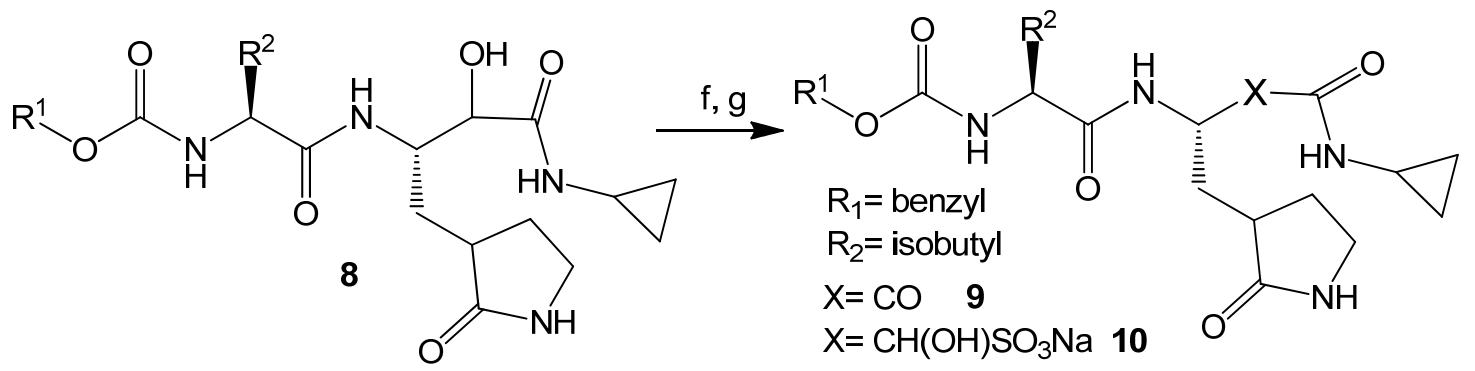

Reagents: (a) $\mathrm{CCl}_{3} \mathrm{O}(\mathrm{C}=\mathrm{O}) \mathrm{Cl} /$ dioxane; (b) Triethylamine/R $\mathrm{R}^{1} \mathrm{OH}$; (c) $\mathrm{LiOH} / \mathrm{THF} / \mathrm{H}_{2} \mathrm{O}$; (d) EDCI/HOBt/DIEA/DMF;

(e) $\mathrm{LiBH}_{4} / \mathrm{THF}$; (f) Dess-Martin periodinane/DCM; (g) $\mathrm{NaHSO}_{3} / \mathrm{EtOAc} / \mathrm{EtOH} / \mathrm{H}_{2} \mathrm{O}$;

(h) Cyclopropyl isonitrile/HOAc then $\mathrm{K}_{2} \mathrm{CO}_{3} / \mathrm{CH}_{3} \mathrm{OH} / \mathrm{H}_{2} \mathrm{O}$. 


\section{FIGURE 1}

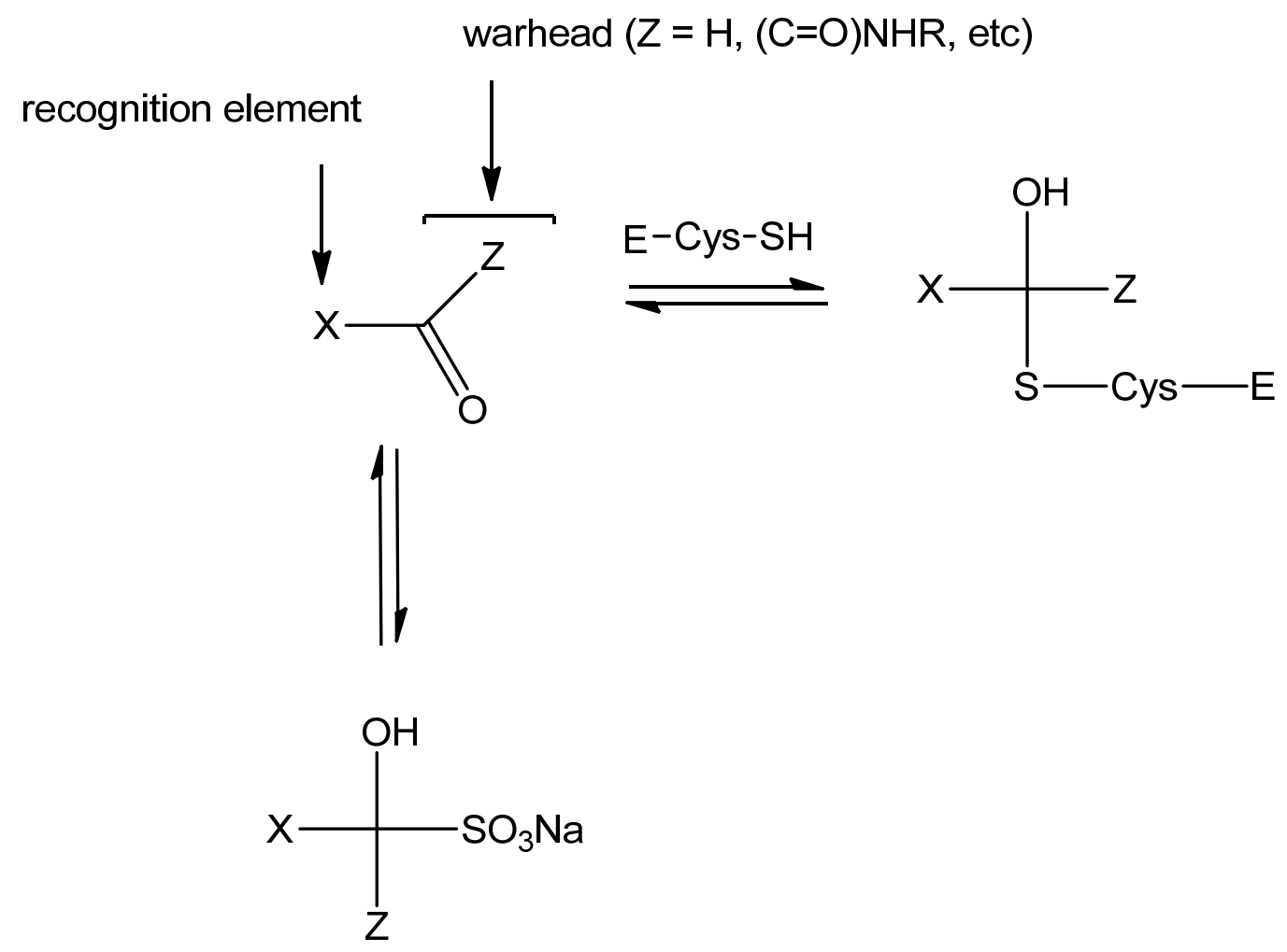

